\title{
Modelling of the changes in land cover in the forest of Sidi Bel'Abbes between 1987 and 2018 and the impact of fires on soil evolution in western Algeria
}

\author{
ayache abbassia $^{1}$, hellal benchaabane ${ }^{2}$, ayad nadera ${ }^{1}$, and bouchenafa nadia $^{3}$ \\ ${ }^{1}$ Universite Djillali Liabes de Sidi Bel Abbes \\ ${ }^{2}$ Universite Ibn Khaldoun Tiaret \\ ${ }^{3}$ Ibn Khaldoun University Tiaret
}

August 6, 2020

\begin{abstract}
The aim of our study is to know the rate of restoration, the reconstitution of the forest landscape and the impact of fires on the resilience of the soils of the Tenira forest. The frequent fires in the latter are one of the main major disruptive factors for the various components of the soil, regeneration and their dynamics. The uses of remote sensing data reduce the cost and time required to assess damage in the forest. It periodically and automatically provides information on very large areas and on several spectral bands. Our approach is based on the chronic study of this forest through the use of landsat sensor data, after collecting real field data. A supervised classification was applied to the selected images in order to identify the types of soils and the vegetation. The analysis of the results obtained showed remarkable of dominance agricultural soils of the type calcisols, calcaric fluvisols and the regeneration of the forest cover in the study area. There is also an increase areas cleared for agriculture which has accelerated soil erosion in this region. Indeed, the intensification of crops requires an increase in inputs which can lead to a decrease in the biological activities of the soil, in particular earthworms. This type of vegetation existing after this fire; indicates the low water storage capacity and the high risk of erosion. The final results generally showed that the rate of recovery of land use and type of soils in the Tenira forest has changed considerably.
\end{abstract}

\section{Introduction}

The forests are a key element in managing the protection and rehabilitation of areas vulnerable to land degradation and erosion. The characteristics of forests and soils are among the main parameters evaluated for natural resource management planning. According toMarion Briens, Dominique Legros and Edouard Michel in the book describing the state of Mediterranean forests in 2013, which the degradation of these lands causes a decrease in agricultural productivity, and compromises essential ecosystem services. At European level, the draft framework directive on soil protection was proposed in 2007. It is based on the observation that $45 \%$ of European soils are degraded and poor in organic matter, and stresses. These degradations result in erosion, compaction, loss of organic matter, salinization, landslides, loss of soil biodiversity, acidification. In addition; overgrazing is one of the major causes of soil degradation, with herds too large in relation to the carrying capacity of their routes which, instead of favoring the growth of pasture, often accelerates the desertification process. These problems could be made worse by the effects of climate change. From 1992 to 2009 , the areas of arable land decreased by 7 million hectares (-13\%) and 4 million hectares $(-9 \%)$ respectively in the agricultural population of the north and south-east Mediterranean countries. The Mediterranean forest is characterized by a dominant woody stratum with dense undergrowth under development. The types of species encountered and shrubs are: olives (Olea europea), cork oaks (Quercus ilex), eucalyptus (Eucalyptus globulus ) and conifers. These latter; are wide, spiny, and possess several important varieties 
such as: maritime pines (Pinus pinaster), aleppo pines (Pinus halepensis) and cedars (Cedrus atlantica ). Today, heterogeneous climatic conditions, agro-pastoral practices, and frequent fires (Trabaud, 1979) threaten Mediterranean biodiversity. The real effect of the latter on the forest ecosystem is a current and major problem for the media. Several authors consider that forest fires can prove beneficial to the health of many forest ecosystems. Prescribed burning and deburring are two management and maintenance operations used worldwide. Indeed, insects, fungi and bacteria of all kinds can proliferate in the clumps of foliage and dead branches that cover the ground. Forest fires are a natural way to sterilize the soil, free up space for the growth of new plants and stimulate the growth of herbaceous plants. However, the relationship between soils and forests is much broader and more complex. They also influence the environment as a whole. This interactions help maintain the environmental conditions necessary for agricultural production (Zammit, 2008). Their moderate intensities have an impact on all soil parameters. According to Assunta Pales and al., 2004; the duration of heating, the maximum temperatures, the moisture content, the type of substrates, the quantity and density of the fuel, the severity of the combustion simulate all the reactions of live telluric species alive in the middle. The immediate effect on soil microorganisms is a reduction of their biomass, and in extreme cases; the soil can undergo complete sterilization (De-Banoand and al., 1998). Fire also modifies the specific composition of the microbial community, its reproductive capacity and catalytic performance is distinguished by its temperature sensitivity (Dunn and al., 1985). According to Certini, 2005; the impact of fire on the soil's biological properties, greatly depends on its humidity levels. The Populations of microorganisms that are physically active in moist soil are more sensitive than dormant populations in dry environment (Dunn and al., 1985). Choromanska and DeLuca (2002) showed that soils of three experienced regions. In Pinus ponderosa andPinus Pseudo-tsugamenziesii ecosystems, their fireinduced microbial biomass decreased at the wettest level and probably due to faster heat transfer than in dry soils. Water allows better leaching than air. Indirectly, we notice on the burned surfaces a modification of the organic matter, which represents the energetic supply, determining the sum of the possible lifespan in the ground. They tend to reduce nutrient levels; however, the concentration and bioavailability of many contents generally increase due to the burning of humus, as well as the mineralization of the constituent elements, which limits subsequent microbial growth. With regard to the fauna of the soil and more particularly the invertebrates. According to Certini, 2005; the direct effects of the fire are less marked than those on the microorganisms, because of the higher mobility which allows a greater potential to escape the heating by deep digging the ground. However, fire reduces litter mass, which significantly reduces the total mass and number of invertebrate species living in the soil. According to Bachelier, 1978; the fire change the microclimate of the soil and by reducing the energy input of plant debris, the bare soil covered with black ash is hotter and drier, with daily increased thermal amplitude. Earthworms, then quiescent in the depth of the soil, are not damaged. On the other hand, micro arthropods suffer a sudden mortality, but easily colonize the medium after a few months. The fire rejuvenates the settlement of arthropods, which, in its absence, evolve towards a more or less different stand, by modifying the environment. According to Vennetier, 2009; in areas usually ravaged by fire, the ecosystem parameters are in equilibrium with their average intensity. Knowing that; stability is maintained around three resources: adaptation of plant species to this diet, ability to rebuild are stocks of organic matter between two fires, viability of soil and humus (fauna, bacteria, fungi). This equilibrium also depends on the physicochemical parameters of the soils modified by fire; they are gradually restored by biological activity. There is therefore a strong interaction between these two phenomena, essential to understand the resistance and resilience of forest ecosystems to fire. The restoration in this depends mainly on the speed of the repopulation of the plant cover. The expected rise in temperatures in the coming years could favor the spread of large forest fires, which would ultimately involve a sharp increase in burned areas (Giec, 2007). According to Ramade (1997), the recurrence of fires has been reduced to 33 years of life expectancy in a Mediterranean reforestation. Quézel and Médail (2003) show that, on average; most Mediterranean sclerophyte plants are covered by fire every 25 years. In this case, the Algerian forests are subject to multiple climatic and anthropogenic attacks (Quézel and Médail, 2003). Kadik, 1987; estimates that he initially covered 7 million hectares; distributed on the northern fringe of the southern foothills of the saharan atlas. This area often represents only 4.1 million hectares dominated by the degraded stratum (DGF, 2000). The deforestation rate is in scale with the climate of northern Algeria; would be reduced from $27.1 \%$ 
to $11 \%$ only. The production area is small and represents only $17 \%$ of the total forest area; $21 \%$ are likely to be improved and $62 \%$ are severely degraded (Kadik, 1987). It characterized by a Mediterranean climate with two distinct seasons that of the rains and the drought, and it provokes a fundamental physical character for their forest (Kadik, 1987). The latter is also known for its susceptibility to fires that are very common in the summer and annually destroy over 37000 ha (Benabdeli, 1996). She lost 1162484 ha between 1979 and 2010 with a total number of 41644 of fires. The broad-leaved species such as oak and beech do not burn as easily as conifers, which are virtually the only component of forests in mountainous regions. Among conifers and pines are more easily burned because of their high resin content. Although conifer needles are extremely flammable, their fields and their branches are significantly less. According to Trabaud, 1992 (a) and (b); the evolution of this forests are constantly conditioned by fires that have a leading role on the dynamics of plant communities in the Mediterranean ecosystem. In this case, the transition of the fire eliminates all vegetation located on the surface and above the soil surface. To know the future of these burned communities, it is essential to follow their evolution over time by carrying out a chronic analysis of which we know the date of the last disturbance. The majority of perennials and plant communities of Mediterranean landscapes are regenerated after fire by vegetative reproduction. Exclusively and rarely case; which species can regenerate by sexual means. In turn, the land clearing is an inevitable destructive action of the vegetation in the place, the final disappearance of the wooded state to another use, widely to respond to needs in the field of agriculture and livestock in the forest. Benabdeli, 1996 and Boudy, 1955; confirm that in the Oranaise region where the reforestation rate does not exceed $9 \%$, the deforestation through land clearing result the intense degradation of chains coastal forests, in addition mainly sheep and goat are often considered primarily responsible for the degradation of plant ecosystems (Alexandrian and Esnault, 1998). According to Benabdeli (1996), the grazing in the forests is a very degrading factor by its aggressiveness and the damage it causes to the vegetation and soil. It is a source of partial or total removal of the vegetation cover. The grazing in forest unregulated imposes significant damage: livestock cut young terminal shoots of trees for food, jeopardizing their growth and sometimes their existence (Seïgue, 1985). This operation facilitates the grazing of the stratum bushy palatable and pruning of shrubs (Benabdeli, 1996). Herds eat forest grains including acorns there by reducing opportunities for regeneration thus compromising its durability. The grazing in forests facilitates the development of carpet herbaceous and can be for farmers an incentive to cause fires (Seïgue, 1985). This contribution aims to study the spatiotemporal evolution of the forest and soil of the municipality of Tenira located in western Algeria. The latter has undergone deep ecological and floristic changes. According to statistics of DGF (2013), each year Tenira forest is burned; whose thousand hectares have been lost. For this purpose; this analysis focuses on the description of the general state of the Tenira forest and soils from 1987 to 2018 using spatial tools of multi-spectral data and medium resolution. The integration of the use of remote sensing linked to forest fires is a real opportunity to bring together the national and international community. The different aspects of management and research will be addressed including, among others, the areas related to fire monitoring and post-fire mapping. In addition to covering a variety of land-to-space uses, this research article also addresses current issues such as drone use, international collaboration, and forest fire costs. Among the main objectives of this contribution is to encourage the community to present the state of frequent capabilities in the field of remote sensing applied to the different phases of forest fire management and research (fire, during fire and after-fire). To understand better the challenges associated with the exploitation of remote sensing and the integration of research results into operational fire management activities. To identify also areas of collaboration to link soil, air and space with the goal of strengthening forest fire management in our country and elsewhere. Bringing together leaders and experts from the remote sensing and fire community to explore, interpret, establish and strengthen collaboration and partnerships in the areas of forest fire research and management.

\section{Study area}

\subsection{Localization}

The province of Sidi Bel'Abbes, located in northwestern of Algeria, occupies a privileged and strategic position, with an area of approximately $9.3 \mathrm{~km} 2$. The locality of Tenira distant of almost $30 \mathrm{~km}$ from the south-east of the plain of Mekerra (Figure 1), between the coordinates of Lambert between 0 deg $35^{\prime} \mathrm{W}$ and 0 
deg 25 ' $\mathrm{W}$ of longitude and between $34 \mathrm{deg} 5$ ' $\mathrm{N}$ and $35 \mathrm{deg} 5$ ' $\mathrm{N}$ of latitude. It covers 16.2 ha. The observation of the digital terrain model (DTM) has shown that the attitude of the forest of Tenira varies between $465 \mathrm{~m}$ and $1051 \mathrm{~m}$. From 1985 to 2013, the forests of Sidi Bel'Abbes received an average annual highest of about $490 \mathrm{~mm}$ and the lowest is of the order of $201 \mathrm{~mm}$. In the same period; mean monthly temperatures range from $16.1 \operatorname{deg} \mathrm{C}$ to $24.7 \operatorname{deg} \mathrm{C}$ (Photos 3).

\section{Figure 1: Location of the study area}

\section{Photos 1: Panoramic view of the Tenira forest in the province of sidi bel'abbes of western Algeria}

\subsection{Typology of soils}

According to Benaouda, 1994; the soils of the Tenira forest are superficial characterized by an enclave between rocky outcrops. The upper horizons of this zone consist of a mixture of sand and calcareous pebbles. Forest soils will evolve under the influence of climatic factors and bedrock (kadik, 1986). The soils of this region belong in most cases to the soils of the mountainous area, calcareous brown soil on calcareous sandstone. On the thuya and the pinerais land covers are: calcareous brown soils, on steep slopes of erosion favor the outcropping of the limestone rock. We meet on tall Pinus alepensus mixed withOak kermes ; the soil type is limestone colluvium with a sandy-loamy texture, the organic matter content is low and can thick. The areas of the recent iso-humic; the brown soil is populated byOak kermes and mastic forest; these soils are characterized by a sufficient amount of organic matter and active limestone (Benaouda, 1994).

\subsection{Land cover}

The forest area of the province of Sidi Bel'Abbes is one of the densest and richest in the west of the country, with a rate of reforestation of $22 \%$. According to 2014 forest conservation data, there are 36 forests, covering an area of 205.6 ha. This resinous constitution of $73 \%$ is highly exposed to the risk of fires that make it more vulnerable (Forest conservation, 2014 and 2017) (Photos 2).

\section{Photos 2: View of the landscape of the forest of Tenira}

\section{Methodology}

\subsection{Data use}

Our study aims to test and use remote sensing to study the evolution and the state of vegetation in the forest of Tenira. Completion of this work will necessitate the availability of the series of satellite data dating from August or September (data 1: 1987, data 2: 1992, data 3: 2002, data 4: 2007, data 5: 2010, data 6: 2013, data 7: 2015, data 8: 2018), details on exploited landsat images are reported in table 1. Data were downloaded from the USGS global visualization viewer glovis on-demand interface (http://glovis.usgs.gov/). They allow us to appreciate the vegetation cover perennials, constituted plant stability element of landscape.

\subsection{Generate of NDVI}

Initially, we tried to analyze the health of the vegetation using the temporal evolution of the vegetation index (NDVI: difference of normalized vegetation index), this index was proposed by Rousse and al., 1974. It is a simple combination of spectral bands without compensation of ground effects, according to the following formula:

$\mathrm{NDVI}=(\mathrm{PIR}-\mathrm{R}) /(\mathrm{PIR}+\mathrm{R})$

It uses the following data: channel near infrared (PIR) and channel red (R).

The values obtained ranging between -1 and +1 , respectively, for the absence and the presence of vegetation. This combination of the standardization by the sum of the two bands tends to reduce the lighting effects or slope on vegetation (Caloz and al., 2001). The author adds that the NDVI is not correlated linearly to biomass density, it has an exponential relationship with the density of green vegetation and saturated in the presence of thick vegetation. 


\subsection{Generate of IR}

This redness index is proposed by Escadafal R. and Huete A. (1991); it allows to distinguishing the surface materials according to the saturation of their color. It is a simple combination of spectral bands, according to the following formula:

$\mathbf{I R}=(\mathbf{R}-\mathbf{G}) /(\mathbf{R}+\mathbf{G})$

It uses the following data: channel green $(\mathrm{G})$ and channel red $(\mathrm{R})$.

The soils with a very light gray outcropping gypsum crust (low IR), the soils with aeolian sail, composed of reddish quartz sand (high IR). When; under the combined effect of agricultural practices, the wind, and their deposits move, the composition of the soil surface is modified and their color as well. By following the variations in the redness index, it is then possible to follow these modifications (Escadafal and al., 1991). The soils and mineral surface materials are the dominant components of arid surfaces; the interpretation of images acquired by satellites over these regions requires knowing and taking into account the corresponding spectral properties. Information of a geological and ecological nature can be drawn from it, by detecting the presence of outcrops of clear materials (limestone, gypsum, salts, etc.), or sand. Only a knowledge of the environment and its different aspects according to the level of degradation makes it possible to use the index IR to diagnose a possible evolution of the state of the environment, positive or negative (Escadafal and Huete ,1991).

\subsection{Supervised classification and validation}

Subsequently, we performed a supervised classification of the values of the NDVI and IC obtained, relying on data collected in the field, we performed the classification of maximum of likelihood using regions of interest (ROIs tools). These are selected carefully on level of the study area using the satellite data processing software (ENVI 5.2). The combination of the two classifications has given maps of vegetation types and the maps of soils in our study area (Figure 2). The validation of the adopted classification of all the years of study was estimated by using points of truth on ground (Figure 3) and confusion matrix. The latter was calculated for each card taking into account the percentage of classification and the accuracy coefficient named Kappa coefficient. According to Girard and Girard, 1999; the scale of this coefficient is as followings:

(i): Excellent classification :> 0.8

(ii): Good classification: between 0.8 and 0.6

(iii): Average classification: between 0.6 and 0.2

Table I: Characteristics of satellite data used

Figure 2: Dendrogram of methodology used for this study

Figure 3: checkpoints of terrain validation

\section{Results}

\subsection{Interpretation of NDVI maps}

The results obtained support our theory of the decline of perennial vegetation in the study area. The regression of the recovery is marked by the reduction of chlorophyll levels. For this purpose, the minimum and maximum NDVI values were disturbed during the observation periods (Figure 4). The rate of the cover vegetation in 1987 was estimated at $49.0 \%$, this value decreased to $4 \%$ in 2018 compared to the total area of the municipality. The production of forest formation maps between 1987 and 2018 after the performance estimate of our classifications mentioned in Table II.

Table II: percentage of classification and kappa coefficient of NDVI index

\subsection{Interpretation of land covers maps}


This means that over $90 \%$ of the pixels of the images have been properly classified to ground-truth data. The typology thus defined consists of nine classes:

- Class 1: Forest of aleppo pine (Pinus alepensis )

- Class 2: Maquis of aleppo pine (Pinus alepensis )

- Class 3: Annual crops

- Class 4: Forest of thuya (Tetraclinis articulata)

- Class 5: Maquis of thuya (Tetraclinis articulata)

- Class 6: Reforestation

- Class 7: Maquis of lentisc (Pistacia lentiscus )

- Class 8: Olive (Olea europea)

- Class 9: Bare ground

Reading statistics classes from 1987 to 2018 showed that the forest landscape of our study area has changed significantly (Figure 4). Note that the forest formations have experienced changes in their percentages between the periods of observations. The percentage of pine forest is (11\% or 1853.9 ha) for the years 1987 and 1992. We note that a decline of this class up to (7\% or 1129.0 ha), (7\% or 1156.4 ha) and (5\% is 831.8 ha) respectively for 2002, 2007 and 2010. But this forest grew again in 2013 and 2018. The maquis of pine also recorded an increase in 2010 and 2018.

\section{Figure 4: Maps of the evolution of forest species of the 1987 to 2018 of study area}

The percentages for the work of reforestation and the olive trees have recorded extremely low values. Annual crops are an important area of the study area, for this class high percentages were noted.

\subsection{Interpretation of IR maps}

The high values of the redness index were observed on fertile and agricultural land. The degraded forest stands show a remarkable decrease in this index, indicating the decrease in organic matter and increase in limestone and silt (Figure 5). The realization of maps of soils between 1987 and 2018 after the performance estimate of our classifications mentioned in Table III.

\section{Table III: percentage of classification and kappa coefficient of IR index}

\subsection{Interpretation of soils maps}

The typology of soils and textures thus defined consists of six classes (Figure 5), these nomenclatures according to: Jones and al, 2013; Faraoun, 2013; Benaouda, 1997; IUSS Working Group WRB, 2015; World Reference Base for Soil Resources 2014, update (2015); International soil classification system for naming soils and creating legends for soil maps and World Soil Resources Reports No. 106. FAO, Rome.

- Class 1: Calcaric Cambisols, with Loam, Silty loam texture and geological substrate are Limestone sandstone, Limestone marl

- Class 2: Rendzic Leptosols, Calcaric Cambisols with Loamy sand, Sandy clay loam, loamy sand textures and geological substrate are limestone sandstone, limestone sandstone and hard limestone.

- Class 3: Calcisols, Calcaric Fluvisols with Sandy loam texture and geological substrate are limestone sandstone and clay.

- Class 4: Humic calcisols, Calcaric Cambisols with loamy texture and geological substrate are limestone sandstone, limestone marl

- Class 5: Leptosols, Calcaric Cambisols with Sandy loam texture and geological substrate are limestone sandstone, limestone marl

- Class 6: Humic Cambisols (Rubic-Brunic) with Loamy texture sand and geological substrate is hard limestone rock.

The analysis of the maps of soil changes in the study area; show us the dominance of agricultural soils of the type Calcisols, Calcaric Fluvisols. The statistics for 1987 and 2018; show a clear increase reached at most $55 \%$ of the total area. In second position Calcaric Cambisols and Rendzic Leptosols, Calcaric Cambisols type 
soils are very marked by average areas of the order of $16 \%$ up to $23 \%$. The humic calcisols, Calcaric Cambisols and Leptosols, Calcaric Cambisols and humic Cambisols (Rubic-Brunic) soils are poorly represented. The most remarkable typologies of textures are : Sandy loam, Loamy sand, Loam,Silty loam and Sandy clay loam.

\section{Figure 5: Maps of the evolution of soils type of the 1987 to 2018 of study area}

\subsection{Analysis of changes in forest of Tenira from 1987 to 2018}

The changes between 1987 and 2018 showed a considerable reduction in reforestation areas at (-93.0\%) and bare soil at (-48.8\%) against an extension of those of the olive areas at (36.8\%) and annual crops at (18.0\%). The regeneration of formation of aleppo pine was low, it marks only an increase of $(+11.6 \%)$ to $(16 \%)$ of its areas of distributions. In the state in 2018; we observed the regression of the maquis of aleppo pine (-19\%), reforestation to $(+76.0 \%)$, bare soil in $(+70.4 \%)$, and annual crops up to $(+34.1 \%)$. In this situation the most abundant soil types are Rendzic Leptosols, Calcaric Cambisols in the northern part of the study area. We also notice the dominance of the soil Calcisols, Calcaric Fluvisols and Humic,Cambisols (Rubic-Brunic). The Calcaric Cambisols type soil cover is clearly regressing (Photos 3 ).

\section{Photos 3 : View of the fire of the forest of Tenira}

\section{Discussion}

The world is currently facing serious and very rapid land degradation. Indeed deforestation and desertification two types of closely related threats are taking on an unprecedented scale on forests. Land clearing, fires, overuse of land, overgrazing, deforestation are causing the destruction of land cover and land. The demand for fuel wood is one of the main causes of deforestation, especially in dry highlands where trees grow slowly. Fires are mainly caused by negligence: uncontrolled discharges, rarely by malicious acts. In addition, it promotes the leaching of organic matter from soils that were part of the forest carbon sink. After the fire, the forest canopy and organic matter in the soil surface horizon (litter and humus) were completely burnt down and destroyed by fire, reducing the protection of the soil (siband, 1972; roose 1980). Unfortunately, our study area has undergone an intense degradation of woodlands, which the maquis is increasing. This degradation of the natural environment leads to the reduction of biological potential and by the disruption of the ecological balance and socio-economic. The forest of Tenira is distinguished by a semi-arid bioclimatic and is generally this vegetation comes in the form of maquis indicating the nature of a local bio-climate (Benaouada, 1997). The high percentages of maquis observed during the study periods is due to the continuing degradation of this dense forest. This decline of the surface of dense forest is the result of an anthropogenic exploitation and frequent fires. This effect adds bioclimatic and soil heterogeneity that has fostered the development and installation of vulnerable species. Fires of shrubs in regions of the Mediterranean climate generally burn with considerable intensity. Average fire return times range from 20 to 30 years to more than a century, and fuel combustion during individual fire events ranges from 1 to $5 \mathrm{~kg} / \mathrm{m}^{2}$ (Olson, 1981). Spatial variation in fire response is widely a result of differences in fuel mass before fire, fuel moisture content, fire weather conditions and site topography. The frequency of fires (both regional frequency and return time) is regulated by the frequency and timing of ignition events, fuel accumulation rates and landscape configuration. The importance of this latter factor has received considerable attention (Minnich, 1983 and 1988; Turner, 1987; Malanson, 1984). The relative impact of topography and space variation of fuels depends on weather conditions and fuel moisture. At moderate to high of this latter, variations in vegetation structure and localized landscape fragmentation (due to past fire history) may determine burning patterns. However, when fuel moisture drops below threshold levels and weather conditions are extreme (such as hot, dry winds), fire may be regulated primarily by wide-scale topographic features such as major rivers or divides (Turner and Romme, 1994). There is general agreement that the above factors regulate Mediterranean climate fire systems, but quantitative estimates of their relative importance are difficult, if not impossible. This is due in part to limited data available, but is also a consequence of the stochastic nature of several of these factors. Thus, it is incorrect to view Mediterranean ecosystem fire regimes as being under finely tuned feedback control. Indeed, the variability in fire regimes resulting from these largely (Christensen, 1987; Christensen and 
Muller, $1975 \mathrm{a}$ and b). The importance of bushy stratum is a remarkable sign of degradation of vegetation often reaching the irreversible stage. Furthermore, fires are a major disruption of Mediterranean landscapes. They are linked to intense human pressures but also to the character of pyrophytique and xerophytic vegetation (Delabraze and Vallette, 1974; Houerou 1980; Tatoni and Barbero, 1995). The current situation of this forest stands as one of the most critical in the Oran region. According to Benabdeli (1996), urgent, effective and radical solutions must be found immediately if we do not want to attend a total disappearance of natural woody vegetation. The main consequences will result in an amplification of the desertification process, that is gaining more and more space through the regression of woodlands and rangelands, erosion, disruption of water systems, the deterioration of the environment and especially by a decline in economic and social productivity of natural resources (Benabdeli, 1996). This increase in forest area is mainly due to the efforts of the forest service in the field of watershed protection by various techniques including reforestation of Pinus halepensis, which constitutes the main essence. Similarly, these improvements are insufficient to protect the forest; we estimate that after 31 years, only $9 \%$ of reforestation work has been done to protect the forest of Tenira. In general, and despite the reforestation campaigns conducted annually since independence, the reforestation rate in Algeria is between $10 \%$ and $12 \%$ only. The reforestation rate remains insufficient to ensure both the physical and biological balance and does not cover the needs of field of forest products, nor the economic revenues for the country (Alexandrian and al., 1999). In the province of Sidi Bel'Abbes, the pastoral activity care is higher and the animals are forced to graze off, especially in state forests. The size of the herd necessarily led to the degradation of the forest and damaging the young plantations (Benabdeli, 1996). Our forests are often solicited by pastors as an auxiliary source for livestock feed (Benabdeli, 1996). The cattle farming remains the most practical at the level of forest areas in high altitudes. More than 1200 000 head of cattle are found in the mountainous forest areas (Benabeli, 1998). The permanent increase in herds imposed a destructive pressure especially on forest areas (Benabeli, 1998). According Bedrani, 1993, if the number of herds is high it easily destroys the protective vegetation cover in forestry. The trampling of the powdery surface of soil causes a reduction in permeability therefore, its water reserves increase by favoring runoff. The clearings leave a strong imprint on the physiognomy of this forest, where large areas have been converted into pasturage and cereal field. The extension of agriculture on the plains of Tenira led at the inhibition on the foothills on the edge of forests. Currently, private populations of farmland on the mountains continue to carry out plowing in different levels of the forest edges, clearings, mountain tops (Benabdeli, 1993). According to the results obtained, the installation of annual crops is very important. Indeed, deforestation and land clearing for agriculture have accelerated soil erosion. By the intensification of crops requires an increase in inputs (fertilizers, mechanization, irrigation, chemical control of parasites and weeds) which can lead to a certain imbalance in the soil, but that the resulting degradation depends on clearing, plant cover, and the cropping system in place. Clearing new lands which are more and more fragile, the biomass of a dense forest ( $>800 \mathrm{t} /$ ha: might believe that the soils are extremely fertile. The rock is so deeply altered that all that remains in the soil cover is quartz, kaolinite, a little iron and aluminum, and some traces of incompletely altered minerals. The roots are concentrated in the surface horizons where organic matter and available nutrients are found. Brutal clearing or poorly adapted cultivation techniques, the humus horizons are stripped there remains only a crusted, compact, inert, almost sterile mineral mass. Biogeochemical assessments show that under natural vegetation (forest or undegraded savannah) the inputs of nutrients by rain, dust and biological returns (roots and meso-fauna) exceed the losses by erosion and by deep drainage. The balance being positive, the forest fallow accumulates on the surface (in the litter and the humus) organic matter capable of storing water and nutrients, and the nutrients that the roots have recovered in depth (Roose, 1980; Beirnaert, 1941; Fauck and al., 1969-77; Godefroy, I974; Roose 1972-82; Lal, 1982). This population exerts continuous pressure on the forest types by clearing and overgrazing this disrupts forest protection and development. However, any clearing interrupts this chain of potential fertilization accumulation. The contributions decrease (reduction of the meso-fauna and the efficiency of the root network to capture the nutritive elements under most cultures) and especially the losses increase. Exporting crops reduces the stock of easily tradable items; $50 \%$ of organic matter is mineralized after 4 years and part of the nutrients released are leached (Fauck and al., 1969; Kang and Juo, 1982). Quezel and al.,1992; argue that in 50 years without a total change of socio-economic and of forest policy, it should theoretically remain 
less than half of the current area covered by forests. The regeneration after 2007 fire was very low especially for the formation of thuya and lentisc. However, regeneration between 2007 and 2010 was significant for groupings of aleppo pine. The progressive destruction of the soil in the root systems of these types of forests prevents optimal recovery of some species, and the trees are close to their ecological limits (sauvages, 1961). According Trabaud, 1992 a; five years are sufficient for the burned resumed woody vegetation. The passage of a fire resulting in the alteration more or less pushed vital organs of the plant, to the foliage, trunk, and roots, it follows a loss of tree vigor that could cause its death. In almost all cases, after the fire, the vegetation quickly returns to its original state without human interference. Heat can destroy underground organs or seeds of survival, and thus greatly limits the regeneration of vegetation, resulting in a floristic impoverishment. The repeated fires result in a marked floristic impoverishment. Thus, many plants do not have time to reach sexual maturity before the passage of a new fire. In these semi-arid areas, in normal circumstances out fires, the vegetation is in continual struggle against the harsh climate, its poor soil nutrient, and organic matter. The passage of a fire even in low intensity translates directly by impairing the vital organs of the plant; at tree, vigor may cause their death (Benabdeli, 1996).

\section{Conclusion}

The planet needs sustainably managed forests to control soil erosion and promote soil conservation. Tree roots stabilize the slopes of ridges, hills and mountains and provide the ground with the mechanical structural support necessary to prevent shallow movements of the land mass: landslides occur only very rarely in areas with heavy cover forest. The forests of the region of Sidi Bel'Abbes are part of Mediterranean forests characterized by floristic heterogeneity. The floristic diversity depends mainly on climatic, edaphic and anthropogenic factors. The mapping of changes in forest and soils of Tenira revealed, after the treatment of data sensor of the summer season between 1987 and 2018, various modifications of this forest cover plant and constitutes a typical model for the evolution of Algerian forests. It appears that different classes of forest species and soils have recorded cases of progression and regression during this period. The forest and agricultural areas are under constant pressure imposed by the climatic conditions; types of land used and repeated fires. The socio-economic parameters are also key factors in the use of soils in forest areas and act on their dynamics. This contribution with these preliminary results will encourage the interested community to think about fire danger assessment; identify fires from forest fires, air quality to monitor and map fire in real time (perimeter, area, propagation rate, intensity); the creation of satellite platforms for monitoring and mapping fire, to encourage the use of drones in fire management. The estimation of carbon emissions strengthen national and international collaboration in the field of remote sensing related to forest fires and place the critical role of this technologies in reducing the costs. Therefore it is necessary to sensitize the population that the restoration of forests in arid zones is vital for soil protection.

\section{Acknowledgement}

I would like to special thank the editor-in-chief, Mr Chris Barrow, for these additions to my work, which give me the opportunity to improve my text each time. Thank you for all the establishments and people who contributed to the conception of this manuscript.

\section{References}

Alexandrian, D. and Esnault, F. (1998). National policies affecting forest fires in the Mediterranean Basin. FAO meeting, 28 to 30 October 1998, Rome, 15p.

DOI: https: //www. fao.org/docrep/x1880e/x1880e0\%.htm

Alexandrian, D. and Esnault, F. and Calabri, G. (1999).Forest fires in the Mediterranean region (Trend analysis of forest fires in the Mediterranean and underlying causes related to policy). Unasylva, 197, 50, 35-41p.

DOI: https: // www. 10.4236/ojog.2018.813145 .

Bachelier, G. (1978). Fauna in the soils. Publications of L'ORSTOM, paris, 391p. 
DOI : full/10.1657/1523-0430 .

Bedrani, A. (1993). The place of steppe areas in the Algerian agricultural policy. Desertification and land use in the Mediterranean. Vertigo; Almeria, Espagne.

DOI: https: //www.10.4000/vertigo.5375.

Benabdeli, K. (1983). Development of a methodology for assessing the anthropozoogene action on vegetation in Telagh region (western Algeria). Doct thesis. Specialty, Aix-Marseille III, $185 \mathrm{p}$.

DOI : https: //www. 28 Fascicule 2, 2002 ISSN 0153-8756.

Benabdeli, K. (1996). Aspects physio-structural and dynamics of forest ecosystems anthropozoogene faces the pressure in the mountains of Tlemcen and the Mountains of daya, Western Algeria.Doct. Are sci. Univ. Djilali Liabes of Sidi Bel'Abbes. 356p.

DOI : https: //www.28 Fascicule 2, 2002 ISSN 0153-8756.

Benabdeli, K. (1998). Socio-economic and environmental impact of the privatization of land on space management and herd management: case of the common Telagh (Sidi Bel'Abbes, Algeria). Rev. Opt. Tells me. CIHEAM, 185-194p.

DOI : https: //www. 28 Fascicule 2, 2002 ISSN 0153-8756.

Benaouada, A. (1997). Phytoecological diagnosis and edaphic and establishing a relationship so1 Vegetation in the forests of Tenira -khodida-touazizine. Magister thesis, University of Tlemcen, Algeria, 116p.

DOI : https: //www. 28 Fascicule 2, 2002 ISSN 0153-8756.

Boudy, P. (1955). Forest Economy North African. Forest description of Algeria and Tunisia. Ed, Larosse, 453p.

DOI:https: //www.persee.fr/issue/jafr_0037-9166_1954_num_24_2.

Caloz, R. Collet, C. (2001). Remote Sensing precise: Digital processing of images of Remote Sensing. Sainte-Foy: University Press of Quebec (Agence Universitaire of Francophonie). Precise Remote Sensing books. Volume III, $390 \mathrm{p}$.

DOI:https: //www.D1145, ISBN 978-2-7605-1145-3.

Conservation of forests in the province of Sidi Bel'Abbes. (2014) . Rapport on prevention system and the fight against forest fires.

DOI: https: //www.10.2478/eko-2018-0022.

Certini, G. (2005). Effects of fire on properties of forest soils. Oecologia 143 (1), 1-10.

DOI: $10.1007 / s 00442-004-1788-8$.

Choromanska, U. DeLuca, TH. (2002). Microbial activity and nitrogen mineralization in forest mineral soils flowing beating evaluation of post-fire effects. soil.biot.biochem.34,265-271.

DOI: 10.1016/S0038-0717(01)00180-8.

D.G.F. (2013). Review and analysis of campaign forests- fires of 2013. 15 p., 09 tab.

DOI: https: //www.10.3832/ifor0098-006.

D.G.F. (2017). Review and analysis of campaign forests- fires of 2017. 20 p., 08 tab.

DOI: https: //www.10.3832/ifor0098-006.

D.G.F. (2000). Plan to fight against forest fires. 38 p., 27 tab., Fig. 
DOI: https: //www.10.3832/ifor0098-006

Delabraze, A. Vallette, G.C. (1974). Study of flammability and combustibility. FAO Consultation on Fire in Mediterranean forests. Technical bulletin on forest fires, R .F.F . N . SP. 171-177p.

DOI:http://documents.irevues.inist.fr/bitstream/handle/2042/20879/RFF_1974_S_T1_171.pdf,sequence=1

DeBano, LF. Neary, DG. Folliot, PF. (1998). Fire's effects on ecosystems. Willy, New york.

DOI:10.1126/science.323.5917.1004.

Escadafal R., Huete A. (1991). Etude des proprietes spectrales des sols arides appliquee a l'amelioration des indices de vegetation obtenus par teledetection. Comptes Rendus de l'Academie des Sciences de Paris, vol. 312, Serie II. p. 1385-1391.

Doi :http://horizon.documentation.ird.fr/exl :doc/pleins_textes/pleins_textes_5/b_fdi_31-32/34390.pdf

Faraoun, F. (2013). Evaluation de la fertilite et cartographie des sols agricoles ; cas de la plaine de Sidi Bel Abbes (Algerie occidentale), these de doctorat, Universite Djilali Liabes de Sidi Bel Abbes, 210p.

DOI: https: //www.

Ferka-Zazou, N. (2006). Impact of space-time occupation of spaces on the conservation of the forest ecosystem the common of Tessala, province of Sidi Bel'abbes, Algeria. Magister thesis, University Aboubekr Belkaid Tlemcen, $275 p$.

DOI: https: //www.

Giec, T. (2007). The assessment of 2007 of climate change: Contribution of Working Groups I, II and III to the Fourth Assessment. Report of the Intergovernmental Panel on Climate Change,103 $p$.

DOI :https: //www. books,isbn/0521880106.

Girard, MC. Girard, C. (1999). Treatment of remote sensing data. P 529.

DOI :https: //www.Dunod/9782100763702.

Hellal, B. Ayache, A. Ayad, N. Hellal, T. (2016). Diachronic analysis of the occupation of the steppe area of the department of Sidi Bel'Abbes (Western Algeria).8th IGRSM International Conference and Exhibition on Remote Sensing 83 GIS (IGRSM 2016), IOP Publishing.IOP Conf. Series: Earth and Environmental Science 37 (2016) 012079. DOI: https: //www.10.1088/1755-1315/37/1/012079.

Jones, A. Breuning Madsen, H. Brossard, M. Dampha, A. Deckers, J. Dewitte, O. Gallali, T. Hallett, S. Jones, R. Kilasara, M. Le Roux, P. Micheli, E. Montanarella, L. Spaargaren, O. Thiombiano, L. Van Ranst, E. Yemefack, M. Zougmore R. (eds.). (2013). Soil Atlas of Africa. European Commission, Publications Office of the European Union, Luxembourg.

Kadik, B. (1987). Contribution to the study of Aleppo pine in Algeria. Ecology, forest measurement and morphology,Ed. OPU. Alger, 508 p. DOI:https://www. 132016110t.pdf/dz/document/

Le Houerou, H.N. (1980). The impact of man and his animals in the Mediterranean forest II (1-2), $p$ 155-174. DOI:https: //www. documents. irevues. inist. fr/bitstream/handle/2042/42559/FM_II_ 2-2_ 155.

Pereira, P. Ubeda, X. and Martin, D. (2012). Fire severity effects on ash chemical composition and water-extractable elements. Geoderma, 191: pp 105-114. DOI : 10.1016/j.geoderma.2012.02.005.

Quezel, P. Medail, R. (2003). Ecology and biogeography of Mediterranean forests. Ed. Elsevier S.A.S., Paris, 571 p. DOI :https: //www.15(3), 271-282 (2003). 
Quezel, P. Barbero, M. Benabid A. Rivas-Martinez, S. (1992).Contribution to the study of forestry groups and pre-forest of eastern Morocco. Studia botanica,10/5790,Salananca. DOI :https: //www. fao. org/docrep/x1880e/x1880e05.

Ramade, F. (1997). Conservation of Mediterranean ecosystems: challenges and prospects. Blue Plan, fascicule ndeg 3 - Ed. Economica, PNUE, Paris. 189 p. DOI :https: //www.ISBN 2-7178-2167-8.90F.

Rouse, J.W. Haas, R.H. Schell, J.A. Deering, D.W. and Harlan, J.C. (1974). Monitoring the vernal advancement and retrogradation (greenwave effect) of natural vegetation. NASA/GSFC Type III Final Re-port, Grennbelt, Maryland, 50 p. DOI: https://www. nasa.gov/archive/casi.ntrs./19730017588.

Sauvage, Ch. (1961). Geobotany research on Moroccan cork oak forest.TV,INST,SC, rabat. DOI: https: //www. 10.1002/fedr.201600026

Seigue, A. (1985). The circum-Mediterranean forest and its problems. Agricultural technology and Mediterranean production. G.-P.Maisonneuve and Larose. 502 p. DOI : https: //www. fao.org/docrep/017/i3226e/i3226e.

Seltzer, S. (1946). The climate of Algeria. 219p. DOI : https: //www.horizon.documentation.ird.fr/exldoc/pleins_textes/divers09-04/29910.

Tatoni, T. Barbero, M. (1995). Ecological approach of Mediterranean forest fires. Ecol.MedXI (3/4), P:7899. DOI: https://www. fao. org/docrep/x1880e/x1880e07.

Trabaud, L. (1992a). Forest fire. Mechanisms, behavior and environment. Select edition, 256 p. DOI: https: //www.afs-journal.org/articles197/AFS_0003-4312_1992_39

Trabaud, L. (1992b). Replies Mediterranean woody plants to the action of fire. Functional Ecology and Evolutionary Centre (C.N.R.S.), Montpellier, France. P. 89-107. DOI: https: //www.afsjournal.org/articles197/AFS_0003-4312_1992_39

Trabaud, L. (1979). Study of fire behavior in garrigue Kermes oak from temperatures and fast propagation of its. Ann. SCI. For,pp 13-38. DOI: https: //www. afs-journal.org/articles197/AFS_0003-4312_1979_36.

Vennetier, M. Ripert, C. (2009) . Forest flora turnover with climate change in the Mediterranean region. Case study in Southeastern France Forest Ecology and Management 258p, S56-S63. DOI: org/10.1016/j.foreco.2009.09.015

Yusiharni, E. Gilkes, R.J. (2012). Changes in the mineralogy and chemistry of a lateritic soil due to a bushfire at Wundowie, Western Australia. Geoderma, 191: $p p$ 140- 150 . DOI : 10.1016/j.geoderma.2012.01.030. 

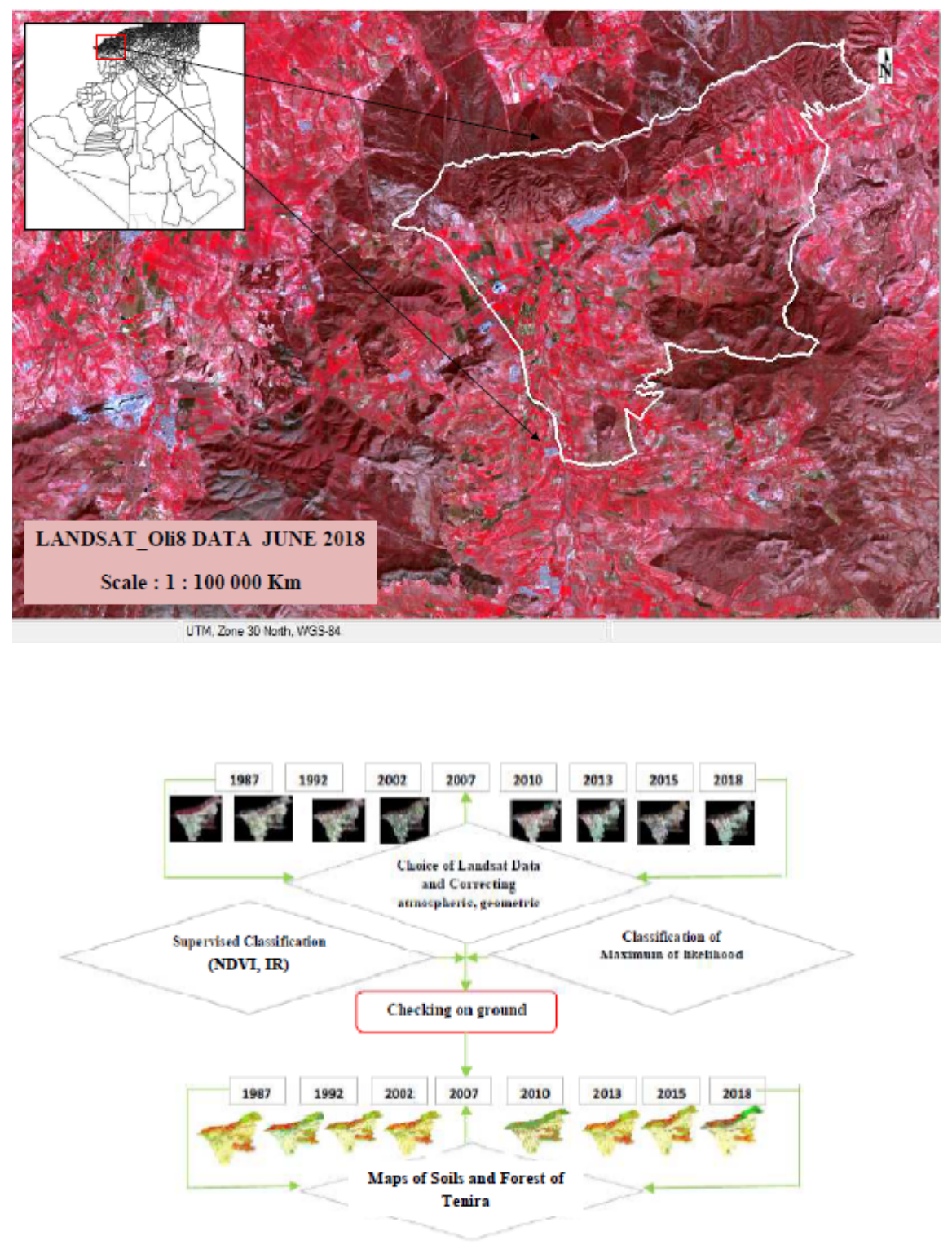


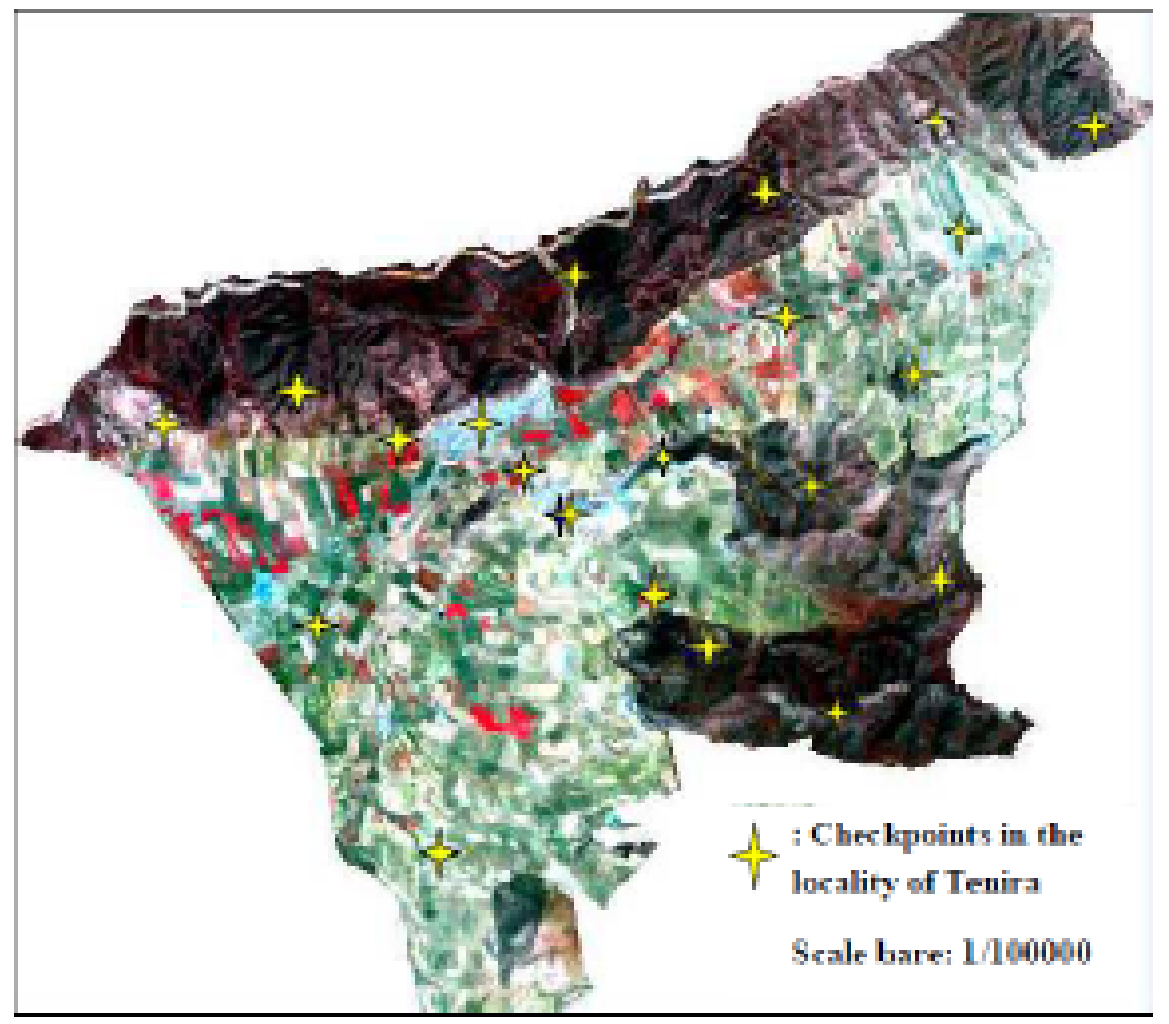



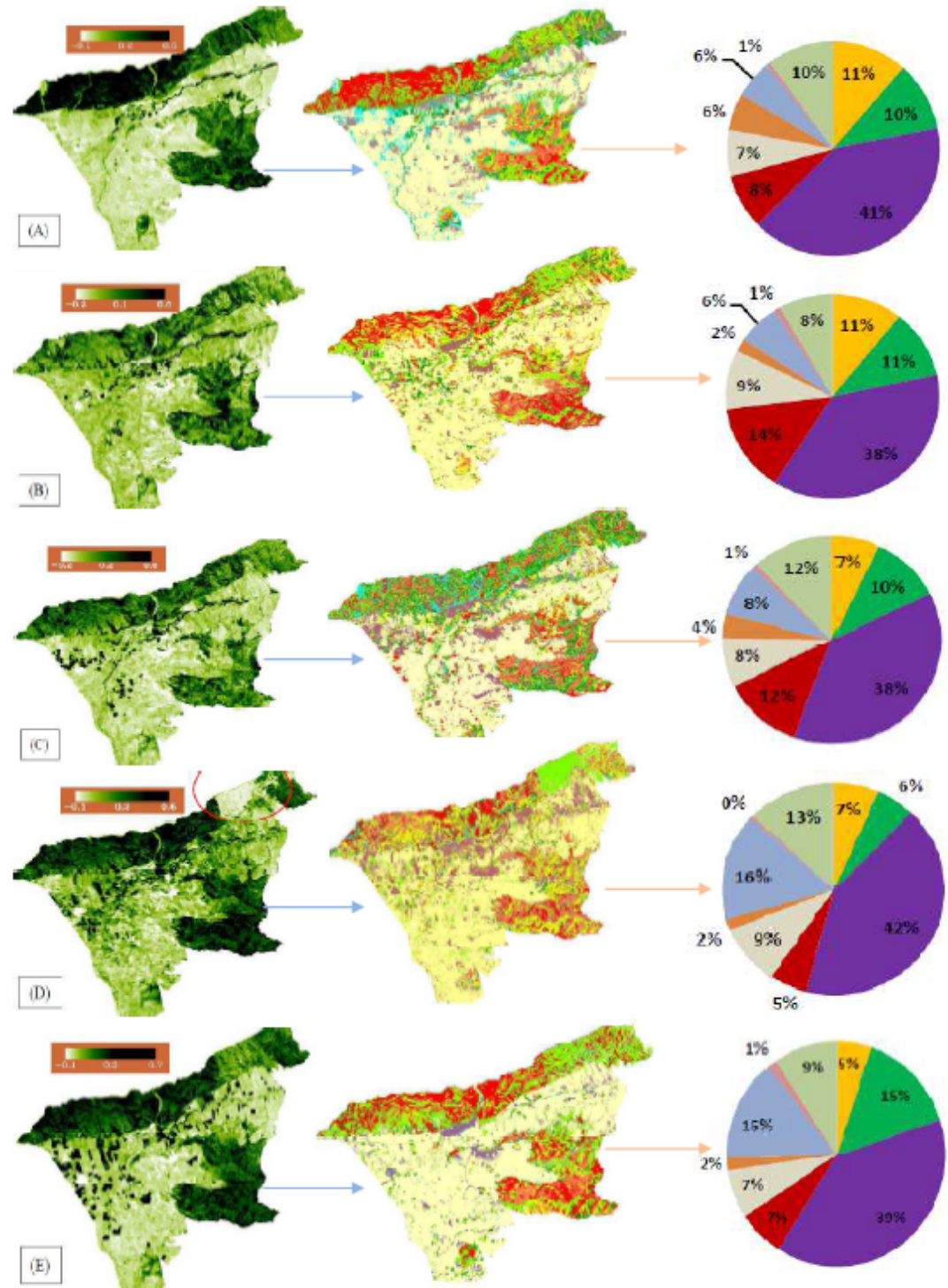


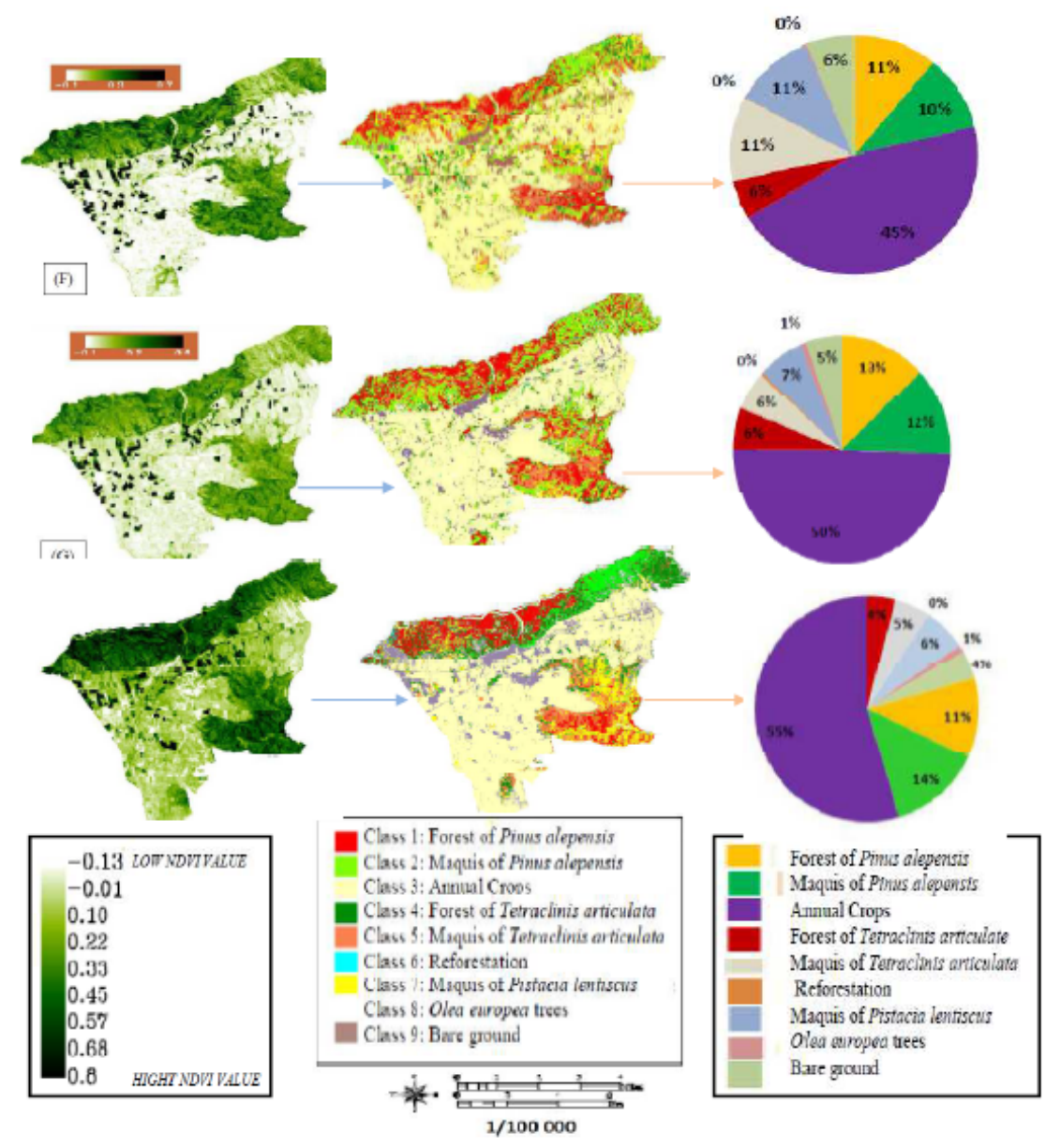

(A): Maps of 1987, (B): Maps of 1992, (C) : Maps of 2003,(D) : Maps of 2007, (E) : Maps of 2010, (F) : Mrps of 2013, (G) ; Maps of 2015, (H) : Maps of 2018, At laft, tis is the maps of changos in NDVI vahes of the study area. At middle; this is the maps of changes of the forest of the study area obtained after classification. Finally at right there are diagrams of the percentage of each class of forest species of study area. 


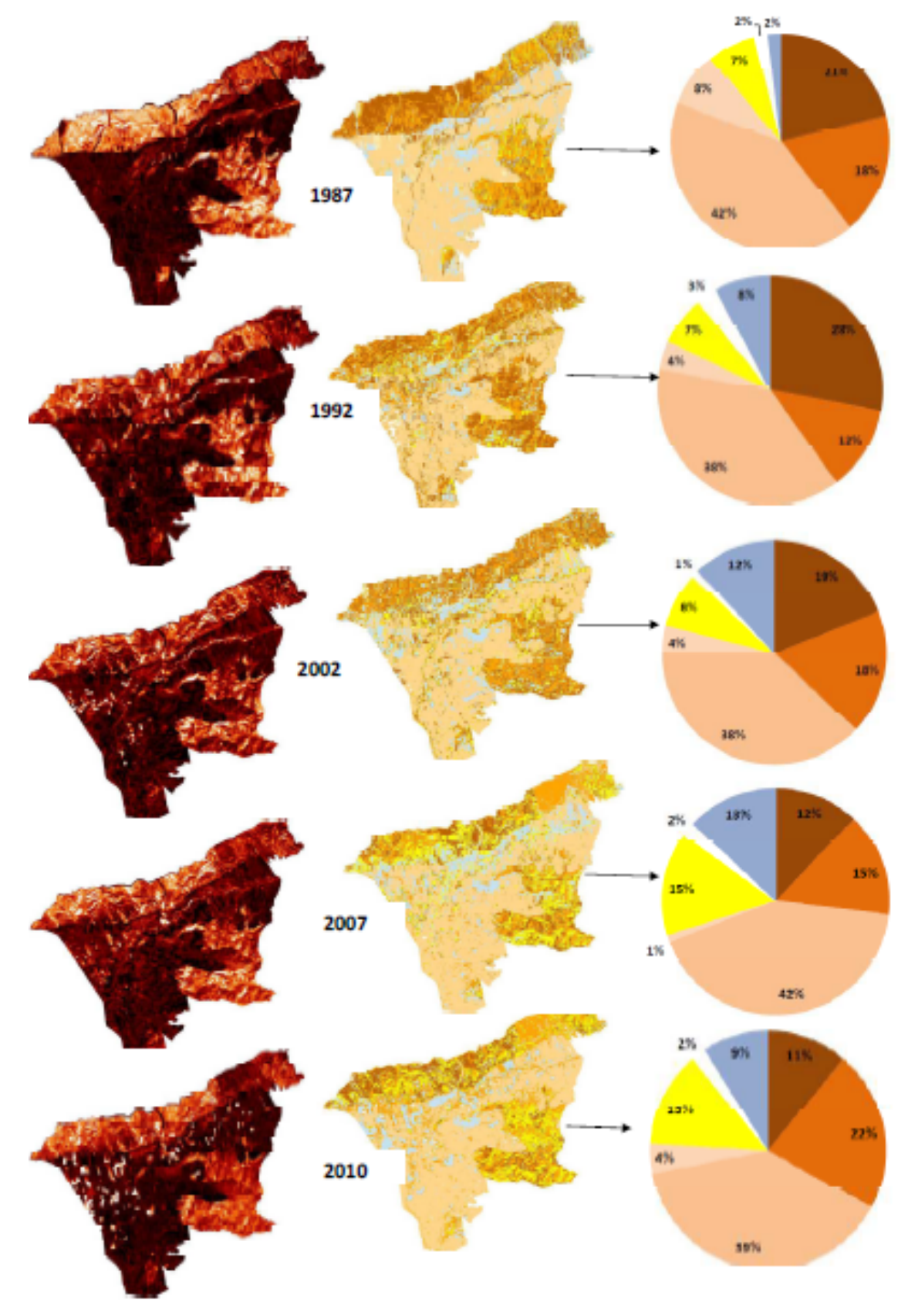




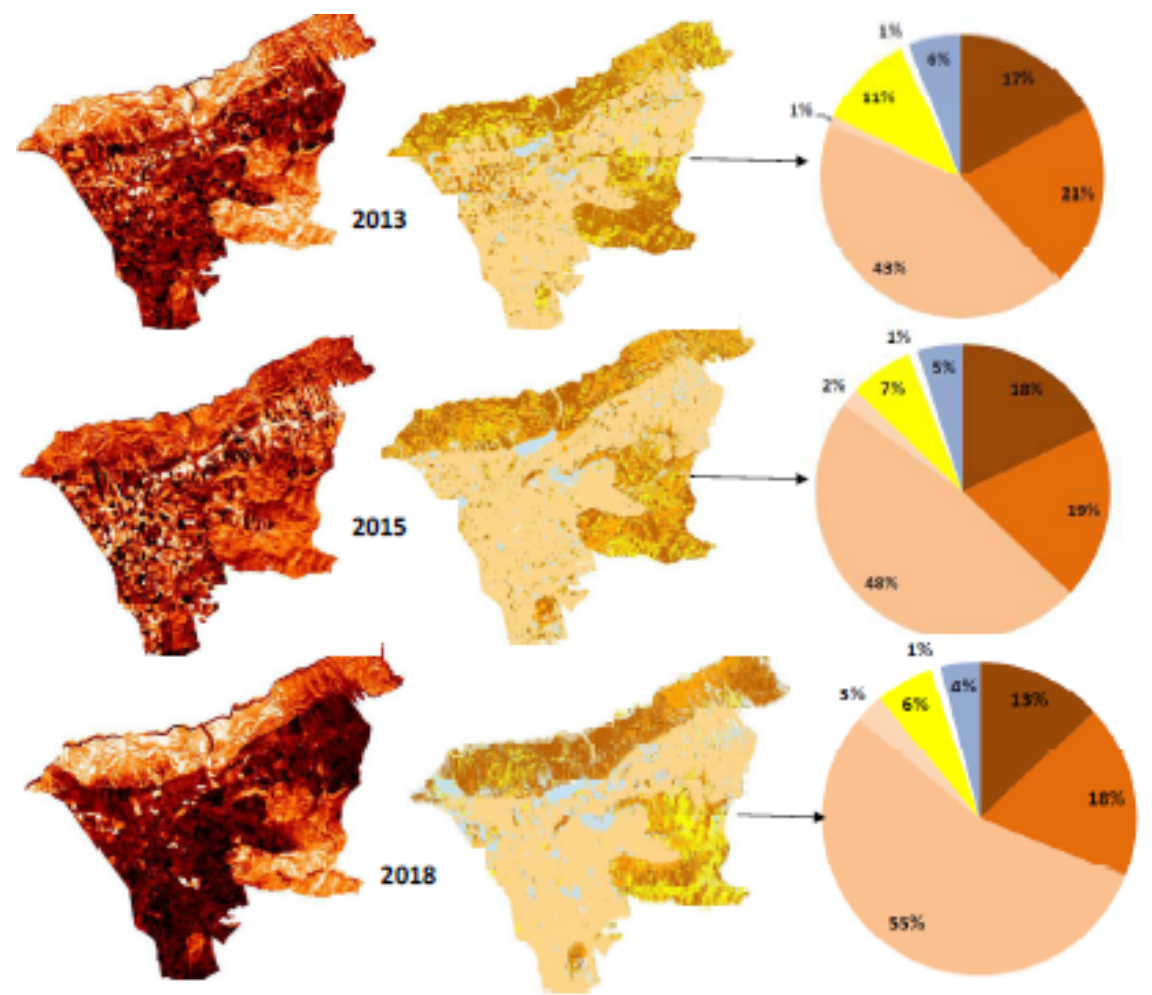

\begin{tabular}{|l||l|}
\hline$-0.106^{\mathbf{V}}$ Low IR Values & Calcaric Cambisols \\
-0.062 & Rendzinc Leptosols, Calcaric Cambisols \\
-0.018 & Calcisols, Calcaric Flurisols \\
0.026 & humic calcisols, Calcaric Cambisols \\
0.070 & Leptosols, Calcaric Cambisols \\
0.114 & humic Cambisols ( Rubic-Brunic) \\
0.158 & Hight IR Values \\
\hline
\end{tabular}

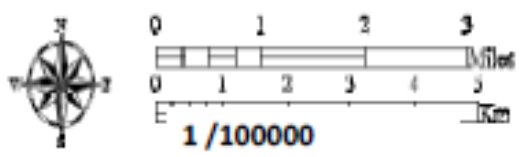

Hosted file

tableaux_ayache_abbassia_AUGUST_2020.docx available at https://authorea.com/users/349258/ articles/474327-modelling-of-the-changes-in-land-cover-in-the-forest-of-sidi-bel-abbesbetween-1987-and-2018-and-the-impact-of-fires-on-soil-evolution-in-western-algeria 

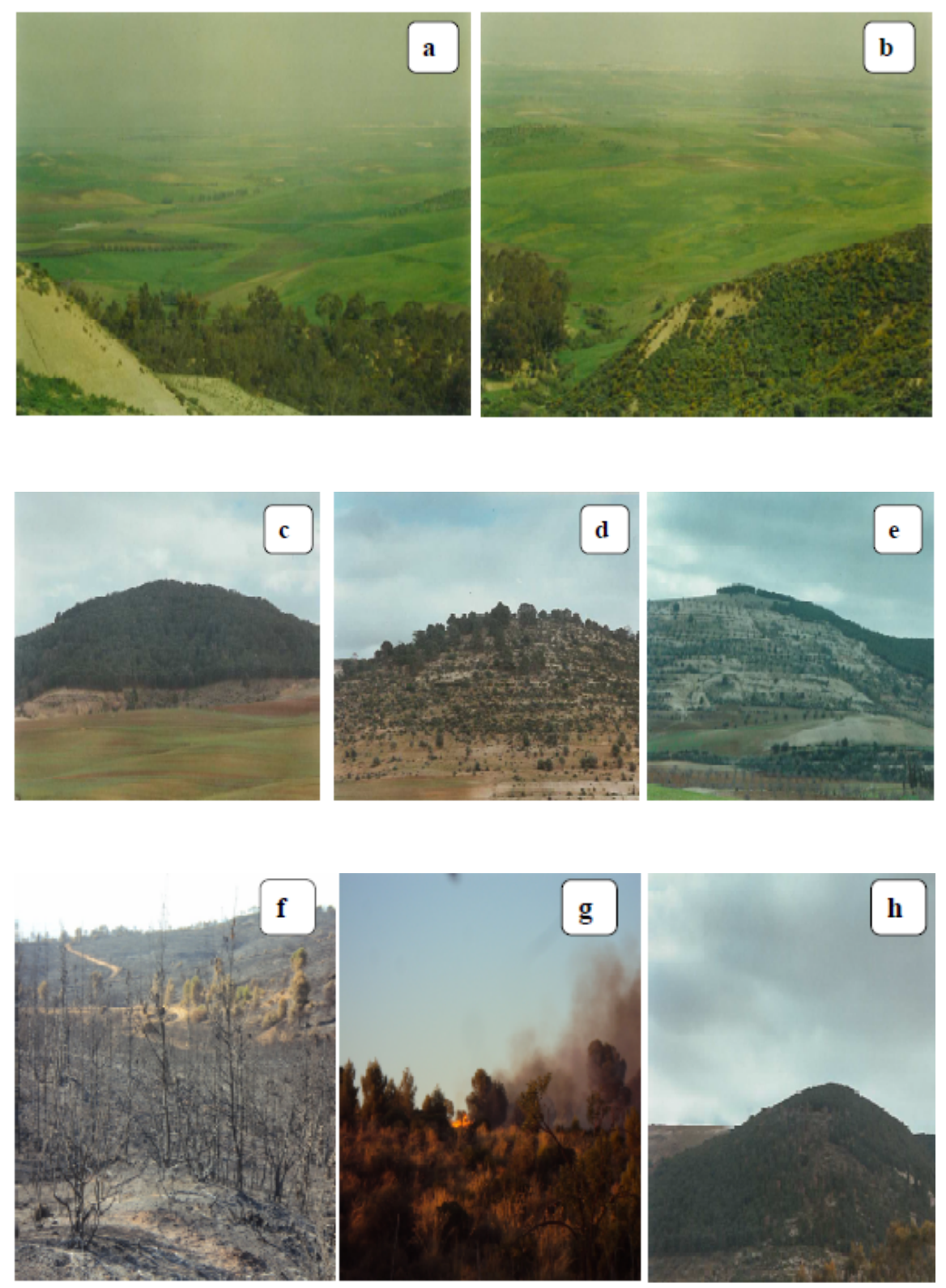